\title{
Karakteristik Marshall Pada Campuran Asphalt Concrete - Wearing Course (AC-WC) Dengan Penambahan Styrofoam
}

\author{
Ika Sulianti ${ }^{1}$ Ibrahim $^{2}$; Agus Subrianto ${ }^{3}$; Adelia Monita ${ }^{4}$ Medici $^{5}$ \\ 1,2,3,4,5 Politeknik Negeri Sriwijaya \\ 1ikasulianti74@gmail.com
}

\begin{abstract}
Styrofoam waste presents the environment issue because it is difficult to decompose. As an effort to recycle this pollutant, styrofoam can be utilized as an additive in asphalt concrete mixture. The use of additives aims to create a flexible pavement layer having good performance and meet the requirements. The purpose of this research is to find out whether the addition of styrofoam can improve the quality of asphalt mixtures, and look for alternative additives that can increase asphalt pavement performance. In this study, researchers used food container styrofoam as an addition and incorforated into Asphalt Concrete-Wearing Course $(A C-W C)$ mixture. The styrofoam content was $6.5 \%$; $6.75 \%$; $7 \% ; 7.25 \%$; and $7.5 \%$ of asphalt weight. The optimum asphalt contentused is $5.5 \%$. The value of the optimum stability was $3126,002 \mathrm{~kg}$, found at $7.25 \%$ of styrofoam content. The best results of Marshall test was obtained at $6.5 \%$ of styrofoam content with stability value $1362,045 \mathrm{~kg}$, VIM value 4,96\%, VMA 15,02\%, VFA 67,8\%, flow 3,44 mm, and MQ 416,338 kg / mm.
\end{abstract}

Keywords: asphalt mixture, pavement layer, marshall test

\begin{abstract}
ABSTRAK
Limbah styrofoam menimbulkan permasalahan lingkungan karena sulit diuraikan. Sebagai langkah untuk mendaur ulang kembali, styrofoam dapat dijadikan bahan tambah dalam campuran aspal beton.Penggunaan additif tersebut bertujuan untuk mendapatkan lapisan perkerasan jalan yang baik dan memenuhi spesifikasi. Tujuan dari penelitian yang dilakukan adalah untuk mengetahui apakah penambahan styrofoam dapat meningkatkan kualitas campuran aspal, dan mencari alternatif bahan tambah yang dapat meningkatkan kinerja perkerasan aspal. Dalam penelitian ini, peneliti menggunakan styrofoam bekas tempat makanan sebagai additif dan ditambahkan ke dalam campuran AC-WC. Kadar styrofoam yang diuji adalah 6,5\%; 6,75\%; 7\%,; 7,25\%; dan 7,5\% dari berat aspal. Kadar Aspal Optimum (KAO) yang digunakan yaitu 5,5\%. Nilai stabilitas optimum didapat pada kadar Styrofoam 7,25\% yaitu sebesar 3126,002 kg. Hasil dari pengujian Marshall campuran styrofoam didapat hasil terbaik pada kadar 6,5\% yang lebih banyak memenuhi syarat dengan nilai stabilitas sebesar 1362,045 kg, nilai VITM 4,96\%, VMA 15,02\%, VFWA 67,8\%, flow 3,44 mm, dan $M Q 416,338 \mathrm{~kg} / \mathrm{mm}$.
\end{abstract}

Kata kunci: campuran aspal, lapis perkerasan, pengujian marshall 


\section{PENDAHULUAN}

Bangunan sipil yang menggunakan aspal sebagai material utamanya salah satunya adalah jalan. Peranan jalan sangat penting dlam keidupan sehari-hari antara lain menghubungkan dari satu tempat ketempat yang lain, meningkatkan waktu tempuh serta memperlancar arus lalu lintas. Perkerasaan yang menggunakan aspal sebagai komponen utama adalah perkerasan lentur. Perkerasan lentur memiliki sifat fleksibel dan dapat menyerap getaran dari kendaraan sehingga lebih nyaman untuk dilewati [1]. Pembuatan campuran aspal telah banyak dikembangkan salah satu nya dengan menambahkan zat aditif. Tujuan dari penggunaan bahan adiktif untuk membuat lapis perkerasan lentur yang kuat, aman, dan memenuhi spesifikasi [2]. Penggunaan bahan aditif dalam campuran dapat berupa limbah rumah tangga.

Limbah didefinisikan sebagai bahan sisa yang dihasilkan dari suatu kegiatan dan proses produksi, baik pada skala rumah tangga, industri, pertambangan dan lainnya. Bentuk limbah dapat berupa gas, debu, cair dan padat. Limbah yang dapat dimanfaatkan sebagai bahan daur ulang seperti limbah plastik diantara limbah plastik yang dapat di daur ulang adalah limbah styrofoam. Penggunaan styrofoam yang semakin banyak berakibat meningkatnya limbah Styrofoam. Styrofoam dikenal sebagai gabus putih yang sering dipakai untuk pengganjal pada pengepakan barang elektronik. Styrofoam adalah sejenis polimer plastik yang memiliki sifat seperti aspal yaitu sifat termoplastik, ketika dipanaskan menjadi lunak dan mengeras kembali setelah dingin. Penggunaan styrofoam sebagai bahan aditif dalam campuran aspal sekaligus untuk menggurangi jumlah limbah styrofoam.

Penelitian yang dilakukan untuk mengetahui apakah penambahan styrofoam dapat meningkatkan stabilitas campuran aspal yang telah direncanakan dengan menggunakan alternatif bahan tambah yang dapat meningkatkan perkerasan aspal. Penelitian terdahulu yang dilakukan Emil Adly [3] didapatkan bahwa seiring bertambahnya styrofoam terjadi penurunan nilai penetrasi dan nilai sifat fisik berat jenis mengalami kenaikan seiring bertambahnya kadar styrofoam [3]. Penelitian yang dilakukan Reni Permanasari dkk [1] yang menggunakan styrofoam sebagai pengganti aspal penetrasi 60/70 dengan kadar 0\%,7\%,8\%,9\%, dan 10\% pada campuran AC-WC didapatkan kadar terbaik yang didapat adalah pada penggantian aspal dengan styrofoam kadar 7\% [1]. Tujuan khusus dari penelitian untuk mengetahui kadar aspal optimum dengan menggunakan bahan tambah styrofoam, mengetahui sifat fisik aspal jika dicampur dengan limbah styrofoam dengan range yang lebih dekat yaitu kadar $0 \% ; 6.5 \% ; 6.75 \% ; 7 \% ; 7.25 \%$ dan $7.5 \%$, dari berat aspal untuk mengetahui pengaruh dari penggunaan styrofoam tersebut terhadap karakteristik marshall pada campuran Asphalt Concrete- Wearing Course (AC-WC).

\section{METODE/PERANCANGAN PENELITIAN}

Penelitian ini menggunakan metode-metode sebagai berikut:

\subsection{Tahap Persiapan}

Tahap persiapan merupakan rangkaian kegiatan yang dilakukan sebelum memulai tahapan pengumpulan data dan pengolahannya.

\subsection{Material yang digunakan}

Material yang digunakan dalam penelitian mengenai pengaruh penggunaan Styrofoam dengan kadar 0\% ; 6,5\% ; 6,75\% ; 7\% ; 7,25\% ; 7,5\% pada campuran Asphalt Concrete-Wearing Course (AC-WC) dengan metode marshall adalah aspal berasal dari PT. Rabana Apalindo, agregat kasar 
menggunakan batu pecah berasal dari Lahat sedangkan agregat halus menggunakan pasir berasal dari Tanjung Raja serta styrofoam yang didapatkan di toko plastik.

\subsection{Perhitungan Benda Uji Aspal}

Pada pengujian ini dilakukan pembuatan sampel benda uji aspal dengan masing-masing kadar sebagai berikut:

1. Jumlah benda uji untuk pengujian kadar aspal optimum dengan 75 kali tumbukan berdasarkan kadar aspal $5 \% ; 5,5 \% ; 6 \% ; 6,5 \%$.

2. Jumlah benda uji untuk pengujian aspal dengan campuran styrofoam dengan 75 kali tumbukan berdasarkan kadar aspal ditambah styrofoam $0 \% ; 6,5 \% ; 6,75 \% ; 7 \% ; 7,25 \%$; $7,5 \%$.

3. Jumlah benda uji untuk pengujian kadar aspal optimum dengan 50 kali tumbukan berdasarkan kadar aspal $5 \% ; 5,5 \% ; 6 \% ; 6,5 \%$.

4. Jumlah benda uji untuk pengujian aspal dengan campuran styrofoam dengan 75 kali tumbukan berdasarkan kadar aspal ditambah styrofoam $0 \% ; 6,5 \% ; 6,75 \% ; 7 \% ; 7,25 \%$; $7,5 \%$.

\subsection{Rencana Kerja Penelitian}

Laboratorium Pengujian Bahan Teknik Sipil Politeknik Negeri Sriwijaya Palembang merupakan tempat dilaksanakan penelitian dengan tahapan - tahapan sebagai berikut:

1. Melakukan pengujian agregat kasar (batu pecah), agregat halus (pasir), filler (semen), styrofoam dan aspal untuk mendapatkan hasil pengujian dari agregat yang diuji.

2. Berikut adalah pengujian yang dilakukan dalam kegiatan penelitian:

a. Pengujian agregat kasar (analisa saringan, kadar air dan kadar lumpur agregat, berat jenis dan penyerapan air, bobot isi agregat, keausan agregat dengan alat los angeles)

b. Pengujian agregat halus (analisa saringan, kadar air dan kadar lumpur, berat jenis dan penyerapan air, serta bobot isi agregat)

c. Pengujian filler (berat jenis, konsistensi semen, waktu ikat semen)

d. Pengujian styrofoam (berat jenis)

e. Pengujian aspal (berat jenis, penetrasi, daktilitas, titik lembek dan titik nyala api)

3. Setelah semua pengujian dilakukan, dicek apakah hasil dari pengujian tersebut sudah memenuhi standar atau tidak.

4. Perencanaan campuran aspal dengan komposisi yang sudah ditentukan dan dilanjutkan dengan membuat benda uji campuran aspal untuk mencari kadar aspal optimum, dengan persentase aspal 5\%, 5,5\%, 6\% dan 6,5\% dan dilanjutkan dengan pengujian Marshall untuk mendapatkan nilai kadar aspal optimum.

5. Pembuatan benda uji campuran aspal menggunakan kadar aspal optimum ditambah dengan styrofoam dengan kadar $0 \%, 6,5 \%, 6,75 \%, 7 \%, 7,25 \%$ dan 7,5\% dari berat aspal, selanjutnya dilakukan pengujian marshall untuk kemudian di analisis dan ditarik kesimpulan.

\section{HASIL DAN PEMBAHASAN}

\subsection{Pengujian Material}

Pada penelitian ini, digunakan beberapa material diantaranya agregat kasar (batu pecah/split), agregat halus (pasir), semen, aspal serta filler yang dipakai pada penelitian ini berupa semen. 


\subsection{Hasil Pengujian Sifat Fisik Agregat}

Penelitian ini menggunakan agregat kasar dan agregat halus. Agregat kasar menggunakan batu pecah yang berasal dari Lahat dan agregat halus menggunakan pasir berasal dari Tanjung Raja. Hasil pengujian berat jenis dan penyerapan agregat halus, kadar air dan kadar lumpur agregat halus, berat jenis dan penyerapan agregat kasar, kadar air dan kadar lumpur agregat kasar, abrasi dengan mesin Los Angeles yang dilakukan memenuhi standar/spesifikasi yang disyaratkan.

\subsection{Hasil Pengujian Sifat Fisik Aspal}

Penelitian ini menggunakan aspal penetrasi 60/70 yang telah memenuhi spesifikasi AASTHO. Pengujian fisik aspal yang dilakukan adalah penetrasi aspal, titik lembek aspal, berat jenis aspal, daktilitas aspal, dan titik nyala aspal.

Tabel 1. Hasil Pengujian Sifat Fisik Aspal

\begin{tabular}{|c|l|c|c|c|c|c|}
\hline \multirow{2}{*}{ No. } & \multicolumn{1}{|c|}{ Jenis Pemeriksaan } & \multirow{2}{*}{ Satuan } & \multicolumn{2}{|c|}{ Spesifikasi } & \multirow{2}{*}{ Hasil } & \multirow{2}{*}{ Keterangan } \\
\cline { 4 - 5 } & & Min & Max & Pemeriksaan & \\
\hline \multirow{2}{*}{1} & Penetrasi pada suhu $25^{\circ} \mathrm{C} 100$ & Mm & 60 & 79 & 74,255 & \multirow{2}{*}{ Memenuhi } \\
\hline 2 & gram $/ 5$ detik & & & & & Memenuhi \\
\hline 3 & Titik Lembek & ${ }^{\circ} \mathrm{C}$ & 48 & 58 & 53,75 & Memenuhi \\
\hline 4 & Daktilitas & ${ }^{\circ} \mathrm{C}$ & 200 & - & 325 & Memenuhi \\
\hline 6 & Berat Jenis & $\mathrm{Cm}$ & 100 & - & 130 & \\
\hline
\end{tabular}

\subsection{Hasil Pembahasan}

Dalam penelitian ini dilakukan pengujian sifat aspal yang dicampur dengan styrofoam dan dilakukan pengujian Marshall yaitu pengujian untuk mengetahui nilai Kadar Aspal Optimum (KAO), kemudian nilai tersebut digunakan untuk penggantian aspal dengan styrofoam. Pengujian dilakukan menggunakan dua sampel dengan tumbukan yang berbeda, sampel pertama $75 \mathrm{x}$ tumbukan untuk lalu lintas berat dan sampel kedua 50x tumbukan untuk lalu lintas sedang.

\section{Karakteristik Marshall Untuk Menentukan Nilai KAO}

Pengujian sampel pertama menggunakan 75x tumbukkan ditampilkan pada Tabel 1 dan 2. Berdasarkan pengujian yang telah dilakukan, kadar yang memenuhi spesifikasi Bina Marga 2010 revisi 3 adalah pada kadar 5,5\% dan 6,5\%. KAO yang dipakai dalam penelitian ini adalah $5,5 \%$.

Tabel 2. Hasil pengujian Marshall untuk penentuan KAO

\begin{tabular}{|c|l|l|l|l|l|l|}
\hline \multirow{2}{*}{ No. } & \multirow{2}{*}{ Parameter } & \multirow{2}{*}{ Spesifikasi } & \multicolumn{4}{|c|}{ Kadar Aspal terhadap berat campuran } \\
\cline { 4 - 7 } & & & $5 \%$ & $5,5 \%$ & $6 \%$ & $6,5 \%$ \\
\hline 1 & VMA & Min. 15\% & 14,856 & 15,104 & 15,070 & 16,178 \\
\hline 2 & VIM & $3-5 \%$ & 5,275 & 4,467 & 3,346 & 3,537 \\
\hline 3 & VFA & Min. 65\% & 64,573 & 70,605 & 77,799 & 78,169 \\
\hline 4 & Stabilitas & $800 \mathrm{~kg}$ & 904,649 & 927,367 & 901.015 & 888,281 \\
\hline 5 & Flow & $2-4 \mathrm{~mm}$ & 3,094 & 3,703 & 3,612 & 3.585 \\
\hline 6 & MQ & Min $250 \mathrm{~kg} / \mathrm{mm}$ & 309,201 & 255,454 & 279,646 & 246,625 \\
\hline
\end{tabular}




\section{Pengujian Marshall penggantian aspal dengan styrofoam}

Selanjutnya dilakukan pengujian pada setiap kadar styrofoam. Benda uji dibuat dengan persentase penggantian styrofoam sebanyak $0 \% ; 6,5 \% ; 6,75 \% ; 7 \% ; 7,25 \%$ dan $7,5 \%$. Kadar aspal yang digunakan adalah 5,5\%. Berikut adalah hasil akhir dari pengujian untuk masingmasing kadar styrofoam yang telah diperoleh berdasarkan rata-rata dari benda uji.

Tabel 3. Hasil pengujian Marshall dengan Variasi Styrofoam

\begin{tabular}{|c|c|c|c|c|c|c|c|c|}
\hline \multirow{2}{*}{ No. } & \multirow{2}{*}{ Parameter } & \multirow{2}{*}{ Spesifikasi } & \multicolumn{7}{|c|}{ Kadar Aspal terhadap berat campuran } \\
\cline { 4 - 9 } & & & $0 \%$ & $6.5 \%$ & $6.75 \%$ & $7 \%$ & $7.25 \%$ & $7.5 \%$ \\
\hline 1 & VMA & Min. 15\% & 15.104 & 15,025 & 15,087 & 15,316 & 15,221 & 15,471 \\
\hline 2 & VIM & $3-5 \%$ & 4.467 & 4,9642 & 5,000 & 5,256 & 5,150 & 5,429 \\
\hline 3 & VFA & Min. 65\% & 70.605 & 67,800 & 67,106 & 65,702 & 66,285 & 64,915 \\
\hline 4 & Stabilitas & $800 \mathrm{~kg}$ & 927.367 & 1362,045 & 1151,534 & 2512,081 & 3126,002 & 1377,314 \\
\hline 5 & Flow & $2-4 \mathrm{~mm}$ & 3.703 & 3,444 & 3,693 & 3,978 & 4,272 & 4,02 \\
\hline 6 & MQ & $\begin{array}{c}\text { Min. 250 } \\
\mathrm{kg} / \mathrm{mm}\end{array}$ & 255.454 & 416,338 & 1297,163 & 667,443 & 774,791 & 362,615 \\
\hline
\end{tabular}

\subsection{Analisis Data Terhadap Nilai karakteristik Marshall Campuran Asphalt Concrete - Wearing Course (AC-WC)}

Berikut adalah pembahasan dari masing-masing parameter Marshall yang telah diperoleh berdasarkan pengujian:

1. Hubungan kadar Styrofoam terhadap nilai VIM

Voids In The Mix (VIM) adalah banyaknya pori diantara butir-butir agregat yang diselimuti aspal dinyatakan dalam persentase terhadap volume beton aspal padat [4]. VIM untuk campuran Asphalt Concrete - Wearing Course (AC-WC) mempunyai batas antara 3\% - 5\% yang sesuai dengan spesifikasi umum bidang jalan raya dan jembatan, Departemen Pekerjaan Umum (2010) [5].

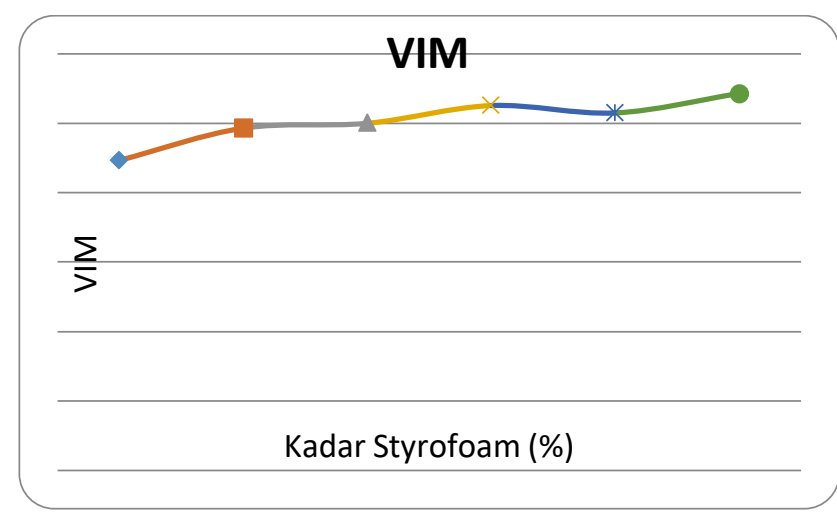

Gambar 1. Hubungan Kadar Styrofoam terhadap nilai VIM

Dari gambar 1 dapat diketahui bahwa dari kadar 6,5\% dan 6,75\% yang sesuai spesifikasi yaitu kadar 6,5\% nilai VIM sebesar 4,931\%, pada kadar 6,75\% nilai VIM sebesar 5,00\%. Nilai VIM cenderung meningkat seiring peningkatan persentase styrofoam. 


\section{Hubungan kadar styrofoam terhadap nilai VMA}

Voids In The Minerals Aggregate (VMA) adalah banyaknya pori-pori antara butir agregat di dalam beton aspal padat dinyatakan dalam persentase darivolume campuran beton aspal [4].

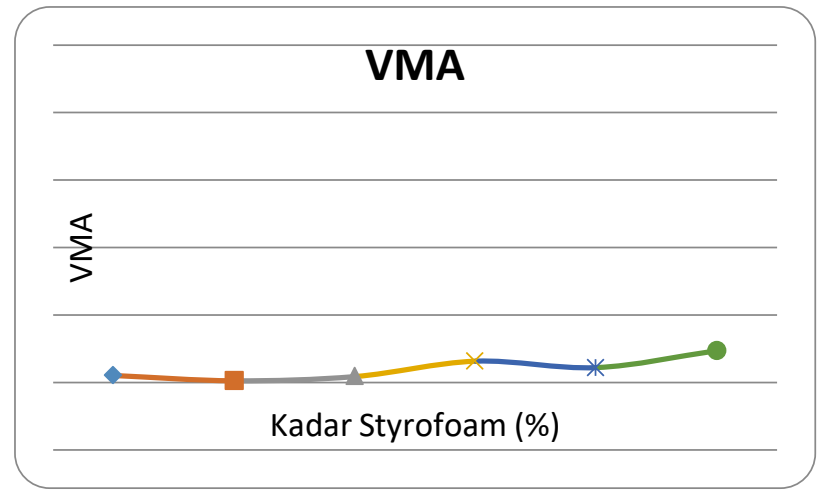

Gambar 2. Hubungan kadar Styrofoam terhadap nilai VMA

Gambar 2 menunjukkan bahwa nilai VMA menurun apabila kadar styrofoam semakin besar dan kembali naik pada kadar 7\% dan 7,5\%. Kadar aspal 6,5\% sampai 7,5\% yang sesuai spesifikasi. Kadar aspal 6,5\% memiliki nilai VMA 15,025\%, kadar aspal 6,75\% memiliki nilai VMA $15,087 \%$, kadar aspal 7\% memiliki nilai VMA $15,316 \%$, kadar aspal 7,25\% memiliki nilai VMA 15,221\% dan kadar aspal7,5\% memiliki nilai VMA 15,471\%. Nilai VMA cenderung meningkat kemungkinan diakibatkan karena sifat aspal yang dicampur Styrofoam akan meningkatkan kekerasan maupun titik lembek aspal sehingga suhu optimal yang dibutuhkan untuk pemadatan juga akan berubah.

3. Hubungan kadar Styrofoam terhadap nilai VFA

Voids Filled Asphalt (VFA) adalah persentase pori antara butir agregat yang terisi aspal [4].

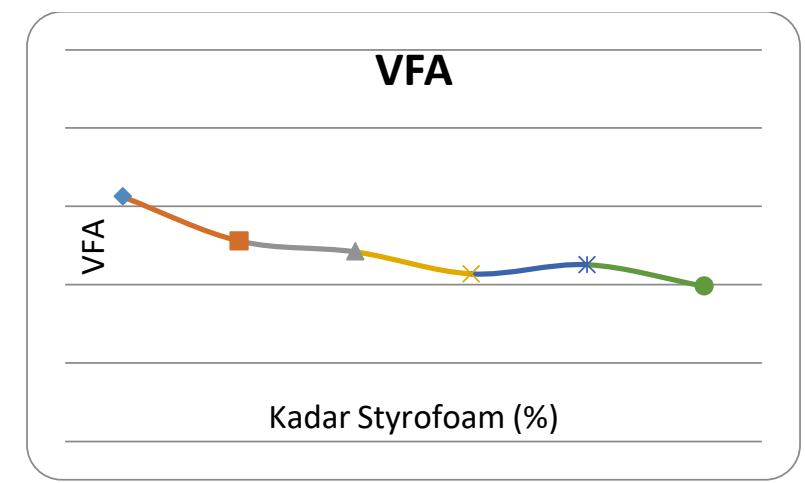

Gambar 3. Hubungan kadar styrofoam terhadap nilai VFA

Gambar 3 menunjukkan bahwa pada kadar styrofoam 6,5\% sampai 7,25\% masih memenuhi persyaratan. Pada kadar 6,5\% nilai VFA sebesar $67,800 \%$, pada kadar $6,75 \%$ nilai VFA sebesar $67,106 \%$, pada kadar 7\% nilai VFA sebesar $65,702 \%$, pada kadar 7,25\% nilai VFA sebesar $66,285 \%$ dan pada kadar 7,5\% nilai VFA sebesar 64,915\%. Peningkatan kadar styrofoam mengakibatkan penuruan VFA. Penurunan nilai VFA diakibatkan oleh meningkatnya nilai VMA. Dengan jumlah aspal yang sama, jika nilai rongga antar agregat 
(VMA) semakin besar maka persentase rongga yang terisi aspal (aspal yang menyelimuti agregat) akan semakin kecil.

4. Hubungan kadar styrofoam terhadap nilai stabilitas

Pemeriksaan stabilitas diperlukan untuk mengukur ketahanan benda uji terhadap beban [4].

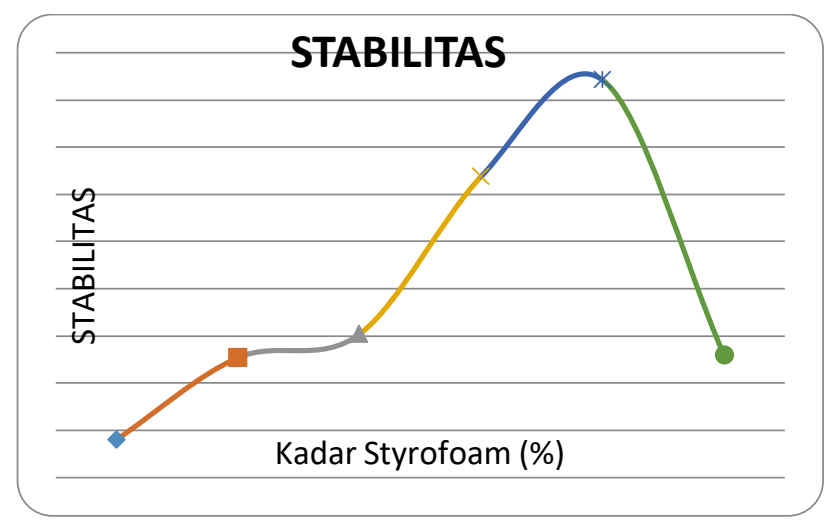

Gambar 4. Hubungan kadar styrofoam terhadap nilai stabilitas

Stabilitas dipengaruhi oleh gesekan internal antar agregat dan sifat kohesi aspal. Sifat kohesi aspal dipengaruhi antara lain penetrasi aspal, perubahan biskositas diakibatkan temperatur, tingkat pembebanan, komposisi kimia aspal, efek dan umur aspal. Stablitas yang tinggi dibutuhkan untuk lalu lintas tinggi sebaliknya untuk lalu lintas ringan tidak dibutuhkan stabilitas yang tinggi. Nilai stabilitas tertinggi terdapat pada kadar styrofoam pada kadar 7,25\% yaitu sebesar 3144,765 kg.

5. Hubungan kadar Styrofoam terhadap nilai kelelehan/flow.

Kelelehan (flow) adalah besarnya deformasi yang terjadi akibat beban [4].

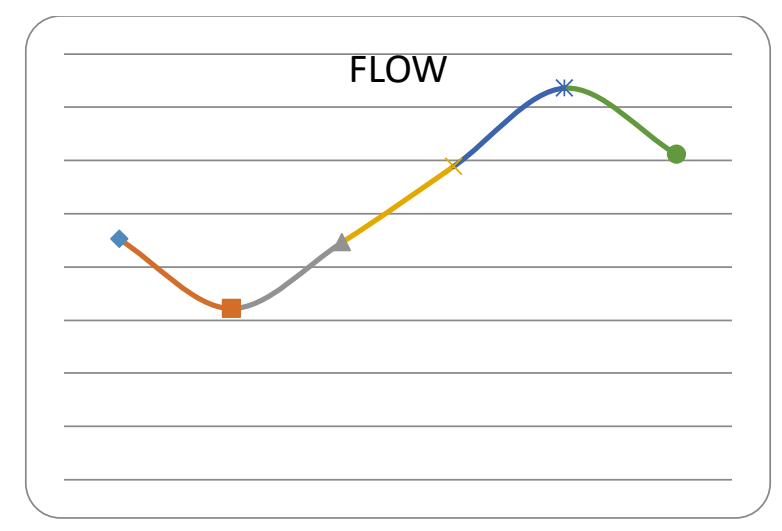

Gambar 5. Hubungan antara kadar styrofoam terhadap nilai kelelehan/flow

Gambar 5 menunjukkan pada kadar styrofoam 6,5\% sampai 7\% memenuhi spesifikasi untuk flow yaitu antara 2-4 mm. Pada kadar 6,5\% didapat nilai kelelehan/flow 3,444 mm, pada kadar 6,75\% didapat nilai kelelehan/flow 3,693 mm, pada kadar 7\% didapat nilai kelelehan/flow 3,978 mm. Kadar styrofoam 7,25\% dan 7,5\% lebih tinggi dibandingkan yang lain sehingga tidak masuk dalam spesifikasi. Pada kadar 7,25\% nilai flow sebesar 4,272 mm dan pada kadar 7,5\% nilai flow sebesar 4,002 mm. 
6. Hubungan kadar styrofoam terhadap nilai Marshall Quotient (MQ)

Marshall Quotient (MQ) adalah rasio antara nilai stabilitas dan kelelehan [4] yang digunakan sebagai indikator kekakuan campuran. Semakin kaku suatu campuran maka semakin tinggi nilai Marshall Quotient (MQ).

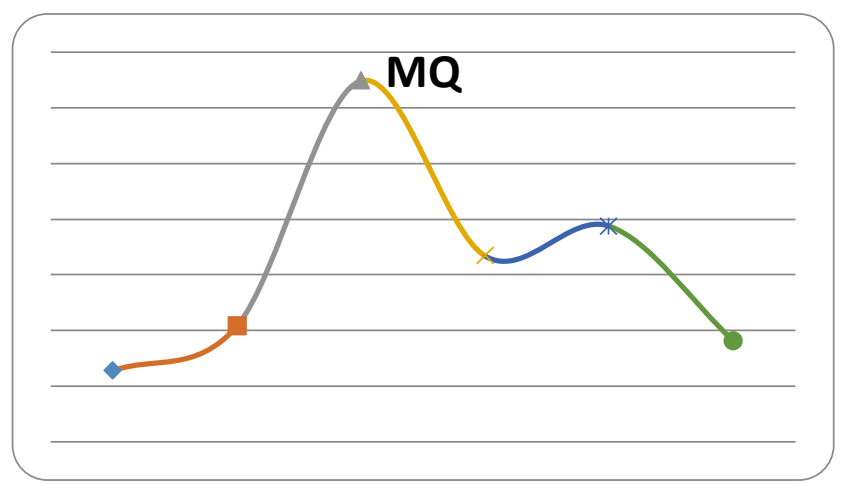

Gambar 6. Hubungan kadar styrofoam terhadap nilai MQ

Gambar 6 menunjukan bahwa pada kadar styrofoam 6,5\% sampai 7\% didapat nilai Marshall Quotient (MQ) meningkat dan menurun kembali pada kadar 7,5\%. Pencampuran dengan styrofoam mengakibatkan sifat campuran menjadi kaku. Namun seiring bertambahnya kadar styrofoam dalam aspal, campuran mulai flesibel kembali, hal itu dapat dikaitkan dengan faktor yang mempengaruhi MQ yaitu kohesi dan temperatur.

\subsection{Pengujian Marshall Untuk Menentukan KAO Menggunakan 50 Tumbukan}

Hasil pengujian sampel dengan menggunakan 50 tumbukkan ditampilkan dalam Tabel 4. Dari pengujian yang dilakukan, kadar yang sesuai persyaratan Bina Marga 2010 revisi 3 yaitu pada kadar $5,5 \%$ dan $6,5 \%$. KAO yang dipakai yaitu $5,5 \%$.

1. Karakteristik Marshall Penggantian Aspal dengan Styrofoam

Pengujian dilakukan pada setiap kadar styrofoam. Benda uji dibuat sebanyak 12 buah dengan persentase penggantian styrofoam sebanyak 6,5\%; 6,75\%; 7\%; 7,25\% dan 7,5\% yang dibuat 3 (tiga) sampel pada setiap persennya. 5,5\% merupakan kadar aspal yang digunakan pada penelitian. Berikut rekapitulasi pengujian Marshall untuk masing-masing kadar styrofoam yang telah diperoleh berdasarkan rata-rata dari tiga benda uji.

Tabel 4. Hasil Pengujian Karakteristik Marshall dengan Variasi Kadar Styrofoam

\begin{tabular}{|c|c|c|c|c|c|c|c|c|}
\hline \multirow{2}{*}{ No. } & \multirow{2}{*}{ Parameter } & \multirow{2}{*}{ Spesifikasi } & \multicolumn{6}{|c|}{ Kadar Aspal terhadap berat campuran } \\
\cline { 5 - 9 } & & & $0 \%$ & $6.5 \%$ & $6,75 \%$ & $7 \%$ & $7.25 \%$ & $7.5 \%$ \\
\hline 1 & VMA & Min. 15\% & 15,204 & 15,077 & 15,085 & 15,362 & 15,407 & 15,570 \\
\hline 2 & VIM & $3-5 \%$ & 4,580 & 4,989 & 4,997 & 5,308 & 5,358 & 5,540 \\
\hline 3 & VFA & Min. 65\% & 70,016 & 66,911 & 66,883 & 65,969 & 65,251 & 64,553 \\
\hline 4 & Stabilitas & $800 \mathrm{~kg}$ & 1022,091 & 1026,61 & 1264,545 & 1117,06 & 1173,34 & 1198,72 \\
\hline 5 & Flow & $2-4 \mathrm{~mm}$ & 3,363 & 2,995 & 3,985 & 3,360 & 3,778 & 4,010 \\
\hline 6 & MQ & $\begin{array}{c}\text { Min. } 250 \\
\mathrm{~kg} / \mathrm{mm}\end{array}$ & 325,286 & 371,552 & 396,670 & 378,694 & 350,284 & 325,278 \\
\hline
\end{tabular}


Vol. 8, No. 2, November 2019, P-ISSN: 2356-1491, E-ISSN: 2655-8211

DOI: https://doi.org/10.33322/forummekanika.v8i2.653

\subsection{Analisis Data Terhadap Nilai Karakteristik Campuran Asphalt Concrete - Wearing Course (AC-WC)}

Berikut ini adalah pembahasan dari masing-masing parameter Marshall yang telah diperoleh berdasarkan pengujian:

1. Hubungan Kadar Styrofoam Terhadap Nilai VIM

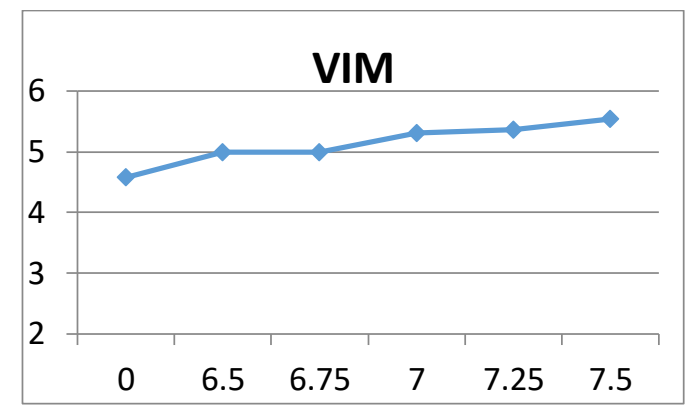

Gambar 7. Pengaruh kadar Styrofoam Terhadap Nilai VIM

Gambar 7 dapat ditarik kesimpulan bahwa kadar Styrofoam 6,5\% dan 6,75\% masih sesuai spesifikasi, namun pada kadar 7\%-7,25\% VIM tidak sesuai spesifikasi dengan nilai perhitungan diatas $5 \%$. VIM yang terlalu besar berakibat pada kurangnya kekedapan terhadap air dan udara sehingga akan mengakibatkan lapisan perkerasan mudah teroksidasi dan cepat mengalami kerusakan. VIM cenderung meningkat seiring peningkatan persentase Styrofoam, hal ini kemungkinan diakibatkan karena sifat aspal yang dicampur dengan styrofoam akan cenderung lebih keras.

2. Hubungan Kadar Styrofoam Terhadap Nilai VMA

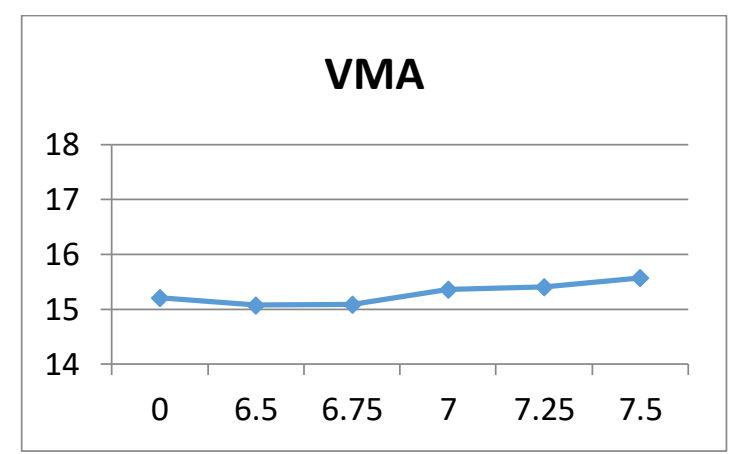

Gambar 8. Pengaruh kadar Styrofoam Terhadap Nilai VMA

Gambar 8 menunjukan nilai VMA ditentukan batas minimalnya oleh Departemen Pekerjaan Umum (2010) yaitu $15 \%$. jika VMA terlalu rendah maka dapat terjadi bleeding. Semakin besar kadar styrofoam yang digunakan VMA semakin meningkat. 
3. Hubungan kadar Styrofoam Terhadap Nilai flow

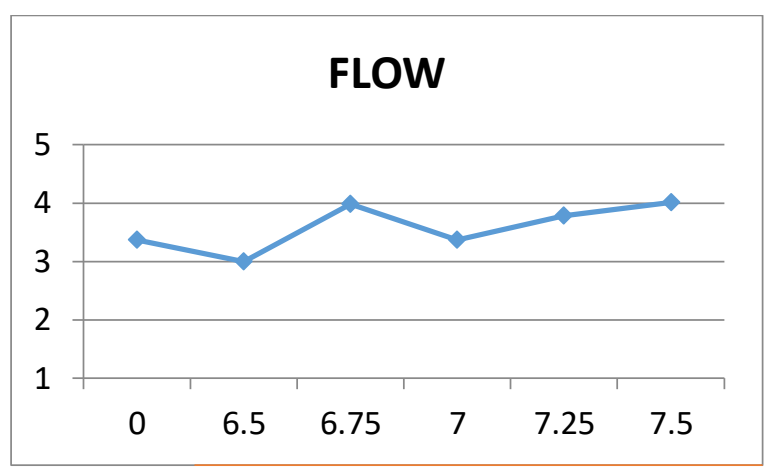

Gambar 9. Pengaruh kadar Aspal Terhadap Nilai Flow

Gambar 9 dapat diketahui bahwa pada kadar 6,5\%-7,25\% flow sesuai spesifikasi, namun kadar aspal 7,5\% nilai flow tidak sesuai spesifikasi dengan nilai perhitungan diatas $4 \mathrm{~mm}$. Nilai flow mengalami penurunan pada persentase Styrofoam 7\% dan semakin meningkat seiring perkembangan styrofoam. Flow yang terlalu besar membuat campuran dengan agregat yang bersifat plastis mengakibatkan campuran mudah berubah bentuk karena beban lalu lintas yang terjadi.

4. Hubungan Kadar Styrofoam Terhadap Nilai VFA

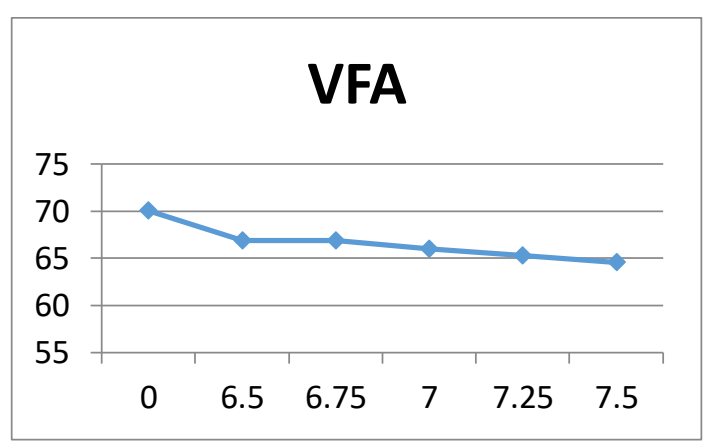

Gambar 10. Pengaruh kadar Aspal Terhadap Nilai VFA

Gambar 10 dapat disimpulkan bahwa pada kadar 6,5\%-7,25\% VFA sesuai spesifikasi, namun kadar aspal 7,5\% nilai VFA tidak sesuai spesifikasi dengan nilai perhitungan dibawah $65 \%$. Peningkatan kadar styrofoam yang digunakan berakibat semakin menurunnya nilai VFA. Penurunan nilai VFA diakibatkan oleh meningkatnya nilai VMA. Dengan jumlah aspal yang sama, jika nilai rongga antar agregat (VMA) semakin besar, persentase rongga yang terisi aspal (aspal yang menyelimuti agregat) akan semakin kecil. 
5. Hubungan Kadar Styrofoam terhadap nilai Stabilitas

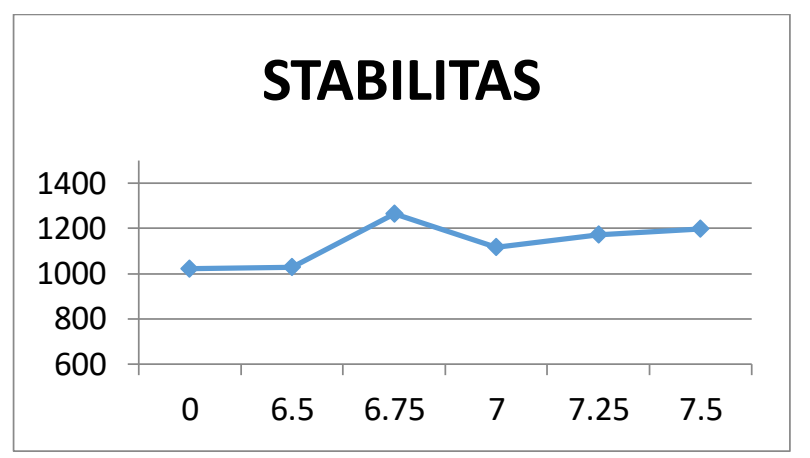

Gambar 11. Pengaruh Kadar Styrofoam Terhadap Nilai Stabilitas

Gambar 11 dapat ditarik kesimpulan bahwa semua variasi kadar Styrofoam masih memenuhi spesifikasi. Stabilitas yang tinggi dibutuhkan untuk lalu lintas tinggi sebaliknya untuk lalulintas sedang sampai ringan tidak dibutuhkan stabilitas yang tinggi. Dikarenakan pengujian ini dikhususkan untuk lalu lintas sedang maka nilai stabilitas yang diambil adalah nilai yang paling rendah. Nilai stabilitas terendah diperoleh pada kadar Styrofoam 6,5\% yaitu sebesar $1026,605 \mathrm{~kg}$.

6. Hubungan Kadar Styrofoam dengan Quotient Marshall

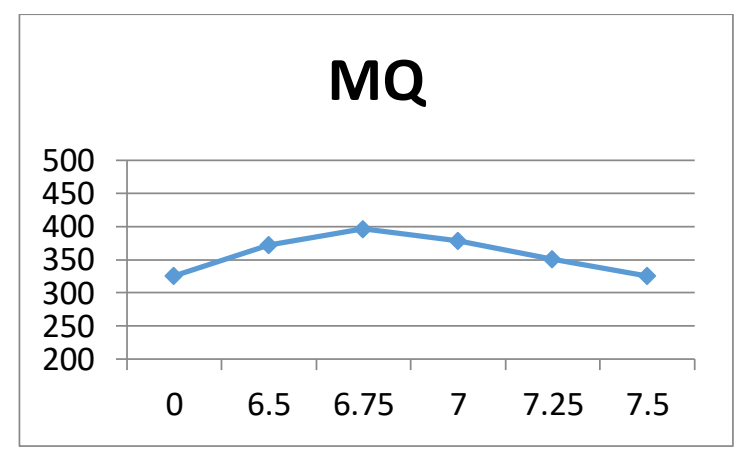

Gambar 12. Pengaruh kadar styrofoam Terhadap MQ

Gambar 12 dapat ditarik kesimpulan bahwa semua variasi kadar Styrofoam masih memenuhi spesifikasi. Nilai MQ cenderung meningkat dari kadar 0\% sampai 6,75\% dan berangsur menurun sampai pada kadar 7,5\%. Hal itu dapat diartikan bahwa pencampuran dengan styrofoam mengakibatkan sifat campuran menjadi kaku. Namun, seiring bertambahnya kadar styrofoam dalam aspal, campuran mulai fleksibel kembali hal itu dapat dikaitkan dengan faktor yang mempengaruhi MQ yaitu kohesi dan temperatur. Karena perubahan komposisi kimia dalam aspal menyebabkan berubahnya sifat kohesi dan viskositasnya terhadap temperatur.

\section{KESIMPULAN DAN SARAN}

Berdasarkan penelitian dan analisis yang dilakukan terhadap campuran laston (AC-WC) menggunakan Styrofoam dapat disimpulkan bahwa kadar aspal optimum 5,5\% diganti menggunakan styrofoam sebesar 6,5\% dari berat aspal dapat digunakan untuk jalan yang dilalui lalulintas sedang dan lalulintas berat. 
Saran yang diberikan penulis untuk dapat ditindak lanjuti adalah perlu adanya teknis pencampuran aspal dengan styrofoam agar pencampuran lebih homogen dan tidak menggumpal, dan penelitian lebih lanjut mengenai temperatur pencampuran maupun pemadatan yang cocok untuk aspal styforoam karena sifat aspal terhadap temperatur berubah setelah dicampur dengan Styrofoam.

\section{UCAPAN TERIMA KASIH}

Terima kasih disampaikan penulis kepada:

[1] Politeknik Negeri Sriwijaya yang memfasilitasi penggunaan laboratorium Pengujian Bahan Jurusan Teknik Sipil.

[2] Mahasiswa Jurusan Teknik Sipil Politeknik Negeri Sriwijaya yang membantu dalam pelaksanaan penelitian di laboratorium.

\section{DAFTAR PUSTAKA}

[1] Permanasari, R, dkk. 2017. Pengaruh Penggunaan Styrofoam sebagai Pengganti Aspal Penetrasi 60/70 dengan Kadar 0\%, 7\%, 8\%, 9\% dan 10\% pada campuran AC-WC. Jurnal Teknik Sipil Fakultas Teknik Universitas Atmajaya Yogyakarta, 1.

[2] Linggo, S.JF. 2015. Penggunaan PVC Sebagai Bahan Tambah pada Beton Aspal. Jurnal Teknik Sipil Universitas Atmajaya Yogyakarta, 190.

[3] Adly, Emil. 2016. Styrofoam sebagai Pengganti Aspal Penetrasi 60/70 dengan Kadar 0\%, 6,5\%, 7,5\%, 8,5\%, dan 9,5\% pada Campuran AC-WC. Jurnal Teknik Sipil Fakultas Muhammadiyah Yogyakarta, 46.

[4] Sukirman, Silvia. 2003. Beton Aspal Campuran Panas. Jakarta, Granit

[5] Departemen Pekerjaan Umum. 2010. Spesifikasi Umum Bina Marga Divisi IV (Revisi 3). Jakarta. 